\title{
INTRODUCTION
}

\section{The Nature of California Air}

It ought to be easy to take California's air for granted. Every day we take about 20,000 breaths, moving more than 3,400 gallons of air in and out, but breathing is an unconscious act most of the time, from the moment of our birth. The balance between photosynthesis and respiration is a fundamental basis for life, yet the air connection between plants and animals remains invisible to many people. And California's relatively undemanding climate makes it even easier to remain oblivious to air as a fundamental fact of life. But despite all this, most Californians actually do consider their air a compelling topic of conversation and concern.

Ancient Greeks saw air as one of nature's basic elements, along with earth, fire, and water. Californians see it....Ah, perhaps those words offer clarification: Californians see too much of something that ought to be less visible. They also feel effects from breathing that air, which too often brings the routine act of respiration to their attention.

Growing up in the southern California coastal basin, I became accustomed to hearing weather forecasts that devoted as much time to inversions and ozone levels as they did to precipitation and temperature forecasts. I was a high school distance runner, and on many evenings it was impossible for me to take a deep breath without triggering a cough from an irritated throat. Although that seemed like a fact of life to be endured, sucking in daily doses of pollutants inevitably kindled my personal interest in air.

What is air? Where does it come from? How does air, in its different manifestations around California, influence us? Why do most people react positively to mountain air or sea 
air? How does desert air differ from the air of the Central Valley? In what ways have we disturbed natural atmospheric processes? How is pollution impacting other organisms that share our landscape? And how is global climate change affecting Californians?

This natural history guide touches on daily weather, seasonal climate, characteristic winds, and sky phenomena. "Air" includes the gases of the atmosphere, but also the aspects of air that influence all of our senses - air's taste, smell, feel, and visible nature. This book further explores our history of air quality management, impacts of air pollution on humans and the broader environment, and technological and individual measures needed to address challenges to air quality.

"The purity of the air in Los Angeles is remarkable. The air ...gives a stimulus and vital force which only an atmosphere so pure can ever communicate" (Truman 1874, 33-34). When Benjamin Truman wrote that description, fewer than 11,000 people lived in the city of Los Angeles and the state's total population was under 600,000 .

The history of California's air quality bears a direct relationship to human numbers and, in the twentieth century and beyond, the number of miles they drive their cars. Since 1940 , over 60 percent of the air pollution in this state has been associated with cars and trucks. In that year, seven million people lived in California. By 2004, population growth had boomed along for six more decades, with only a few brief slowdowns, and the populace had swelled to more than 36 million, with most of us living in southern California or the greater Bay Area and in several inland urban centers. Back in 1940 (pl. 1), Californians owned about 2.8 million motor vehicles. By 2000, the much larger population drove 23.4 million cars and trucks. Total vehicle miles traveled in those six decades jumped from 24 billion to 280 billion; with a population five times as large, we were traveling 20 times as far.

The connection between vehicles and air pollution did not immediately become obvious. 




Plate 1. Covina Valley, 1941. Palm trees outline orchards, with the San Gabriel Mountains in the background. Image by Spence Air Photos.

In the summer of 1943, the state's first severe smog episodes occurred in Los Angeles. Visibility dropped to only three blocks. People complained of smarting eyes, raspy throats, and nausea. The nation was at war, so perhaps the headline in the Los Angeles Times on July 27, 1943, was understandable: "City Hunting for Source of 'Gas Attack.'” The "gas attack" was actually "smog," and the "enemy" attacking Los Angeles' air quality would eventually be recognized as us, each of us, who contributes pollution to the shared atmosphere.

"Smog" was a term that combined "smoke" and "fog" to describe deadly air pollution episodes in England. More than 4,000 deaths occurred in London in a 1952 episode. The English smog came from coal burning that produced sulfur dioxide and soot particles. Southern California's new air pollution problem originated from different sources and had a different chemistry. At first, many blamed one synthetic rubber 
manufacturing plant, but the situation did not improve when the butadiene factory was shut down. In time, Los Angeles' air pollution would be identified as a distinct type termed "photochemical smog," or sometimes just "Los Angeles-type smog."

The new governor of California in 1943 was Earl Warren. He was concerned about the unknown hazards from this new phenomenon. He recommended legislation to:

authorize research to determine what the effect of smog is on the health of the people of the state. The reception given to that suggestion was really something. One would think I had robbed the treasury. Los Angeles was the only county in the state where smog was known to be a problem at that time, and the entire Los Angeles delegation rose in its wrath and declaimed, "This is our own local problem and we will solve it ourselves." They were cheered by the lobbyists for the oil refineries, the oil companies selling gasoline, the truckers who fouled the air with the exhaust of their diesel fumes, rubber manufacturers, garbage burners, and other elements of the smog culture. The legislators of the rest of the state were not particularly interested... and my bill went down the drain without a hearing. (Warren 1977, 229)

Air pollution is a diffuse problem, the shared fault of many emitters. It is a classic example of "the tragedy of the commons." Each of us using the common resource, the atmosphere, makes choices based on our individual benefits, yet the costs are dispersed among the entire population. The benefits of car ownership are very personal, but the pollution that comes from our car is a minuscule fraction of the entire smog problem. It is only because there are so many cars that they create regional air pollution. The problem seems too big for any individual to resolve.

Governments exist to address such challenges to the public welfare. Despite objections by industry, in 1945 the city of Los Angeles did establish its first air pollution control pro- 
gram: the Bureau of Smoke Control. The bureau first targeted emissions from stationary sources like oil wells, refineries, and factories.

Statewide authorization for air pollution control districts in every California county arrived in 1947. The federal government lagged behind. In 1955, a Federal Air Pollution Control Act was enacted that provided for research and technical assistance to better understand the causes and effects of air pollution, but it lacked any regulatory clout. California established a state Bureau of Air Sanitation within the State Department of Public Health in 1959. The Motor Vehicle Pollution Control Board was also created to test and certify emission control devices for cars sold in the state.

The Federal Motor Vehicle Act of 1960 required only more research to address pollution from motor vehicles. Finally, in 1964, the Federal Motor Vehicle Air Pollution Control Act provided for direct regulation by the federal government. The Department of Health, Education, and Welfare was directed to establish auto emission standards.

Yet, when California adopted auto tailpipe emission standards for hydrocarbons and carbon monoxide in 1966, they were the first standards of their kind in the nation. The next year, the California Air Resources Board was created by merging the California Motor Vehicle Pollution Control Board and the Bureau of Air Sanitation.

The 1967 Federal Air Quality Act established a framework for air quality control regions based on weather and topography. Recognizing California's leadership in this area and its unique need for more stringent controls, the act also gave the state a waiver to set and enforce its own emissions standards for new vehicles (pl. 2). This special status would become controversial, eventually, after other states began voluntarily adopting California's higher standards against the wishes of polluting industries.

California's smog problem peaked in the 1970s. Significant progress against the encroaching pollution occurred in 
Plate 2. Smog fills the Los Angeles basin and the Inland Empire region in 1969, piling against the San Gabriel Mountains.

the following three decades, despite a growing population and a steady increase in miles driven. The South Coast Air Basin had no Stage 1 smog alerts for ozone in 2000, dropping from 42 in 1990, 102 in 1980, and 121 back in 1977 (fig. 1).

The state, it seemed, had turned a corner. More and more people began to believe that there might not be a smog problem much longer. Progress, however, was not yet victory. We had to be careful not to declare, "Mission accomplished," before the task was completed. Unfortunately, most southern Californians and residents of the Central Valley still breathed the worst air in the nation. Although incidents of the most severe ozone violations were way down, according to the California Air Resource Board, levels of ozone and particulate pollution continued to impair health and were linked to too many early deaths.

Air could not yet be taken for granted in California. In 2003, the Public Policy Institute of California's "Special Survey on Californians and the Environment" found that most of the 


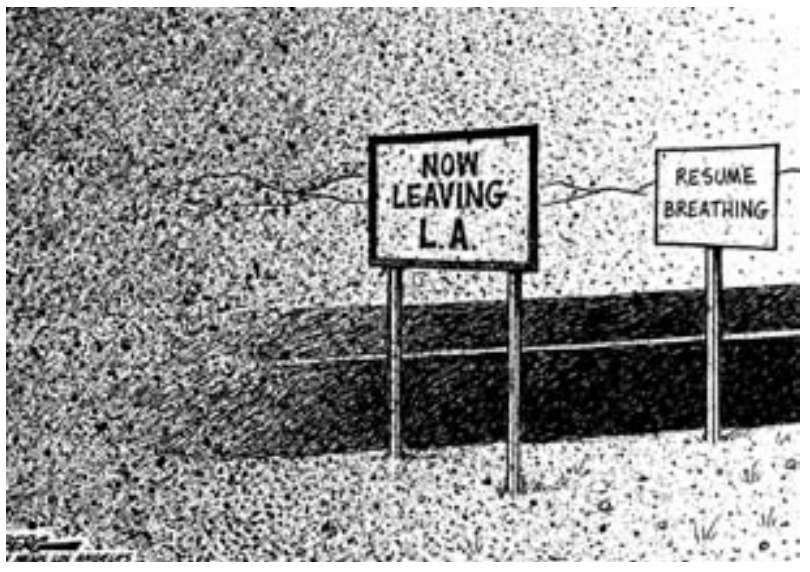

Figure 1. Cartoon in the Los Angeles Daily News.

state's residents viewed air pollution as a serious health hazard and the most critical environmental matter facing the state. Central Valley residents were most likely to regard air pollution as the state's top environmental issue, even more than those in Los Angeles County. Most of those surveyed (65 percent) indicated their willingness to support stricter air pollution regulations on new cars, trucks, and sport utility vehicles, even if such standards would increase new-car prices.

After growing up in southern California, I embarked on a career as a state park ranger, which allowed me to experience air around this state. The coast's salty sea breezes were far different from the Central Valley's sultry summer heat. The haze of both the coast and the valley made sharp contrasts to the deep blue of Sierra Nevada skies. Desert air felt and tasted different than the atmosphere beneath redwood rainforests. Years at Mono Lake revealed connections between local dust storms and distant urban growth. Legal wrangling over water diversions that endangered that inland sea was resolved partly because of air quality requirements. The level to which the lake will be refilled was set by determining how much dry 
alkaline lake bed needed to be re-covered to control unhealthy dust storms and to comply with air standards. That local air should be impacted by the growth of a thirsty metropolis 350 miles away was one sign of many atmospheric connections across this large state.

This book is a natural history guide, but one that recognizes the overwhelming role of humanity in the story of air in California. "The Thin Blanket" explores the nature of the atmosphere and the chemical essence of air. "Air Apparent" is a field guide to the sky, explaining color and light, clouds and wind, and the nature of flight. "California Air Basins" describes regional differences of topography and weather, and the character of air in the state's 15 designated air basins. "Footprints in the Air" covers ways we have altered the atmosphere of California, damaging ourselves and other life in the state. "Sharing Air with the Globe" addresses the challenge of global climate change in California. Finally, "Breathing Easy" explores how we have addressed all of these challenges and suggests further actions each of us can take to improve the state's air quality and be better stewards of the global climate. 


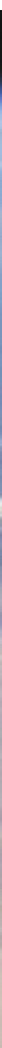